\title{
COXEN Score 30
}

National Cancer Institute

\section{Source}

National Cancer Institute. COXEN Score 30. NCI Thesaurus. Code C128227.

A score of 30 on the COXEN Sensitivity Scale. 